\title{
PERSEPSI IBU TENTANG TOILET TRAINING PADA ANAK USIA TODDLER DI WILAYAH KERJA PUSKESMAS KEDUNGMUNDU KOTA SEMARANG
}

\author{
Dita Wasthu Prasida, Maftuchah, Nirawati \\ Email: dita.stikesyahoedsmg@gmail.com
}

\begin{abstract}
Abstrak
Latar Belakang: Jumlah balita yang masih susah mengontrol BAB dan BAK di usia sampai pra sekolah menurut Survey Kesehatan Rumah Tangga diperkirakan mencapai 75 juta anak, kasus mengompol pada anak usia enam tahun di Indonesia tercatat sekitar 12\%. Hasil studi pendahuluan di puskesmas kedungmundu, dari lima ibu yang memiliki anak usia toddler, tiga ibu mengatakan anaknya masih sering mengompol dan belum pernah melatih anak dalam buang air, sedangkan dua diantaranya sudah mulai melatih.Tujuan Penelitian: Penelitian ini untuk mengeksplorasi persepsi ibu tentang toilet training pada anak usia toddler.Metode Penelitian: Penelitian ini menggunakan metode kualitatif dengan pendekatan fenomenologi. Teknik pengumpulan data dengan wawancara mendalam. Jumlah partisipan 4 orang, triangulasi yaitu suami partisipan.Hasil: Wawancara mendalam pada partisipan didapatkan informasi tentang cara ibu dalam membiasakan anak untuk buang air, usia yang tepat untuk melatih anak, dampak dari toilet training, upaya orang tua serta hambatan-hambatan dalam toilet training.Ibu balita agar melatih anak untuk toilet training mulai usia satu sampai tiga tahun, Petugas kesehatan agar lebih meningkatkan penyuluhan secara menyeluruh terkait toilet training pada anak usia toddler.
\end{abstract}

Kata kunci : Persepsi; toilet training; usia toddler.

\section{The Mother's Perception About Toilet Training on Children Toddler in Kedungmundu District Health Care, Semarang City}

\begin{abstract}
Background: The total of infants who are still hard to control bowel and bladder in age to preschool according to Household Health Survey is expected around 75 million children, cases of bedwetting in children aged six years in Indonesia was about $12 \%$. The results of a preliminary study in Kedungmundu health care center, five mothers who has children toddler, three mothers said their children still bedwetting often and had never train a child to bowel or bladder, while two of them have already started to train.The aim of study: The aim of this study to explore the mother's perception about toilet training on children toddler.Methods:This study used a qualitative method with phenomenological approach. Data collection techniques used in-depth interviews. The total of participant were 4 people, the triangulation is the husband of participants.

Suggestion:The results of in-depth interviews with participants obtained information about the mother's way in used to children to bowel or bladder, the right age to train the children, the effects of toilet training, the efforts of parents and the obstacles in toilet training. Mothers in order to train the children to toilet training ranging in age from one to three years, Health official order to further increase overall education related to toilet training on children toddler.
\end{abstract}

Keywords: Perception;toilet training; toddler

\section{Pendahuluan}

Masalah tumbuh kembang anak merupakan masalah yang perlu diketahui atau dipahami sejak konsepsi hingga dewasa yang menurut WHO hingga mencapai usia 18 tahun. Salah satu bentuk ganguan tumbuh kembang pada anak yang harus diperhatikan adalah enuresis (mengompol), yaitu pengeluaran air kemih yang tidak disadari yang sering dijumpai pada anak diatas empat tahun. ${ }^{[1]}$ 
Jumlah balita yang masih susah mengontrol BAB dan BAK di usia sampai prasekolah menurut Survey Kesehatan Rumah Tangga(SKRT tahun 2008) diperkirakan mencapai 75 juta anak. Kasus mengompol pada anak usia 6 tahun di Indonesia tercatat sekitar 12\%. Kejadian anak mengompol lebih besar jumlah persentase anak laki-laki yaitu 60\% dan anak perempuan $40 \%$. Statistik menunjukan $25 \%$ anak mengompol pada usia 5 tahun akan menurun 5\% pada usia 10 tahun (Kemenkes RI.2010). ${ }^{[2]}$

Hasil studi pendahuluan yang telah di lakukan di Puskesmas Kedungmundu Kecamatan Tembalang, pada tanggal 18 Agustus 2016 pada ibu yang memiliki anak usia toddler, dari 5 ibu 3 diantaranya mengatakan anaknya yang berusia 2 dan 3 tahun masih sering mengompol, dan selama ini orang tua belum pernah melatih anaknya untuk buang air sendiri ditoilet, dan 2 diantaranya mengatakan anaknya sudah jarang mengompol, karena ibu sudah melatih anaknya untuk buang air secara mandiri.

Berkaitan dengan hal tersebut, maka dapat dirumuskan permasalahan yaitu bagaimanakah Persepsi Ibu Tentang Toilet Training pada Anak Usia Toddler di Wilayah Kerja Puskesmas Kedungmundu Kota Semarang? Sesuai dengan rumusan masalah di atas, tujuan dari penelitian ini, yaitu mengeksplorasi persepsi ibu tentang toilet training pada anak usia toddler di wilayah kerja puskesmas kedungmundu kota semarang. Tujuan khusus penelitian ini, yaitu (1) Mengeksplorasi persepsi ibu tentang toilet training pada anak usia toddler (2)Mengeksplorasi upaya yang dilakukan orang tua terhadap keberhasilan toilet training pada anak (3) Mengeksplorasi hambatan dalam toilet training pada anak.

\section{Tinjauan Teoritis}

Persepsi merupakan proses internal yang bermanfaat sebagai filter atau metode untuk mengorganisasikan stimulus, yang memungkinkan individu menghadapi lingkungannya. Proses persepsi dengan mekanisme melalui stimulus yang diseleksi dan dikelompokan dalam wujud yang berarti, yang bersifat otomatik dan bekerja dengan cara yang sama pada masingmasing individu sehingga secara tipikal menghasilkan persepsi-persepsi yang berbedabeda. ${ }^{[3]}$ Persepsi dapat didefinisikan sebagai suatu proses yang ditempuh individu-individu mengorganisasikan dan menafsirkan kesan-kesan individu agar memberikan makna bagi lingkungan sekitarnya. ${ }^{[4]}$

Toilet training adalah suatu usaha untuk melatih anak agar mampu mengontrol dalam melakukan buang air kecil (BAK) dan buang air besar (BAB). ${ }^{[5]}$ Toilet training merupakan proses pengajaran untuk mengontrol buang air besar (BAB) dan buang air kecil (BAK) secara 
benar dan teratur. ${ }^{[6]}$ Toilet training baik dilakukan sejak dini untuk menanamkan kebiasaan yang baik pada anak. ${ }^{[6]}$

Toddler adalah anak antara rentang usia 12 sampai 36 bulan. Toddler tersebut ditandai dengan peningkatan kemandirian yang diperkuat dengan kemampuan mobilitas fisik dan kognitif lebih besar. Perkembangan fisik, perkembangan perawatan diri sendiri seperti makan, berpakaian, dan eliminasi. Peningkatan ketrampilan daya gerak, kemampuan untuk melepas pakaian termasuk melepas celana pada saat anak akan buang air besar atau buang air kecil, dan perkembangan kontrol spingter uretra dan spingter ani memungkinkan anak usia toddler ini melakukan toilet training. ${ }^{[1]}$

\section{Metode Penelitian}

Metode penelitian yang digunakan dalam penelitian ini adalah kualitatif dengan pendekatan fenomenologi. Penelitian ini dilaksanakan pada bulan Juni 2016 sampai Februari 2017, di Wilayah Kerja Puskesmas Kedungmundu Kota Semarang. Partisipan dalam penelitian ini adalah ibu yang memiliki anak usia toddler yang sesuai kriteria dan pemilihannya dibantu oleh key person, dalam penelitian ini yang menjadi key person adalah kader posyandu. ${ }^{[8]}$ Penelitian ini juga menggunakan triangulasi yaitu suami partisipan.Penelitian ini akan berhenti jika data yang terkumpul dalam penelitian telah mencapai saturasi ketika dua partisipan melakukan tindakan yang sama.Instrumen dalam penelitian kualitatif adalah peneliti itu sendiri ${ }^{[9]}$ Wawancara dalam penelitian ini dilakukan 15-30 menit yang bertujuan untuk mengeksplorasi persepsi ibu tentang toilet training pada anak usia toddler di wilayah kerja puskesmas kedungmundu Kota Semarang. Dalam penelitian ini, peneliti juga menggunakan alat perekam, buku catatan dan kamera. Tahapan dalam mengumpulkan data, yaitu tahap persiapan, wawancara, dan penutup. Selanjutnya, cara pengolahan data menggunakan analisis kualitatif. ${ }^{[9]}$ Pengolahan data kualitatif dilakukan dengan tiga langkah, yaitu reduksi data (data reduction), penyajian data (data display) dan penarikan kesimpulan (conclusion drawing and verification).$^{[10]}$.

\section{Hasil Penelitian}

Cara dalam membiasakan anak agar tidak mengompol, berdasarkan wawancara yang telah dilakukan pada 4 partisipan, dapat dilihat bahwa adanya persamaan jawaban antara partisipan 1, 2, 3dan 4 tentang kebiasaan melatih anak untuk buang air secara mandiri yakni: membiasakan anak agar tidak mengompol adalah membiasakan anak untuk buang air pada pagi hari setelah bangun tidur, ataupun malam sebelum tidur.Usia yang tepat dalam toilet 
training, berdasarkan wawancara yang telah dilakukan, dapat dilihat bahwa adanya persamaan jawaban antara partisipan 1, dan 3 tentang usia yang tepat melatih anak untuk toilet training, yakni pada usia satu setengah tahun.

Perlukah toilet training dilakukan, berdasarkan wawancara yang telah dilakukan, dapat dilihat bahwa adanya persamaan jawaban antara partisipan 1, 2 dan 3, yaitu bahwa membiasakan anak untuk buang air sejak dini perlu dilakukan untuk melatih kemandirian anak dan membiasakan untuk berprilaku hidup bersih dan sehat, berbeda dengan pernyataan partisipan 4 bahwa membiasakan anak untuk buang air sejak dini perlu dilakukan agar anak tidak menjadi terbiasa menggunakan pampers hingga besar.

Dampak tidak dilaksanakannya toilet training, berdasarkan wawancara yang telah dilakukan dengan 4 partisipan, dapat dilihat bahwa adanya persamaan jawaban antara partisipan 1, 3 dan 4, yaitu bahwa dampak apabila anak tidak dilatih sejak dini untuk buang air anak menjadi tidak mandiri, selalu bergantung dngan orang tua, malas dan manja, berbeda dengan pernyataan dari partisipan 3 yang menyatakan bahwa dampak apabila anak tidak dilatih sejak dini untuk buang air yaitu anak menjadi tidak teratur dan suka buang air sembarangan

Persiapan dalam Toilet Training, berdasarkan wawancara yang telah dilakukan dengan 4 partisipan, dapat dilihat bahwa adanya persamaan jawaban antara partisipan 1, 2 dan 3, yaitu bahwapersiapan selama melatih anak dalam melatih buang airnya harus melihat minat dan kemauan dari anak itu sendiri, berbeda dengan pernyataan dari partisipan 4 yang menyatakan bahwa persiapan selama melatih anak untuk buang air yaitu menghindarkan anak dari rasa takut/trauma terhadap kamar mandi.

Jadwal dalam melatih anak untuk buang air, berdasarkan wawancara yang telah dilakukan dengan 4 partisipan, dapat dilihat bahwa adanya persamaan jawaban antara partisipan 1, 2 3, dan 4 yaitu bahwa bahwa tidak ada jadwal yang pasti dalam melatih anak ketika buang air, tetapi orang tua selalu membawa anak ke toilet saat bangun tidur, maupun pada malam hari sebelum tidur.

Berdasarkan wawancara yang telah dilakukan dengan 4 partisipan, dapat dilihat bahwa adanya persamaan jawaban antara partisipan 1,2 3 dan 4, yaitu bahwa bahwa suami ikut berperan dalam melatih anak.Hambatan atau kendala dalam toilet training, berdasarkan wawancara yang telah dilakukan dengan 4 partisipan, dapat dilihat bahwa adanya persamaan jawaban antara partisipan 1 dan 3 yaitu bahwa hambatan atau kendala ketika melatih anak untuk buang air yaitu ketika anak rewel dan tidak mau di ajak ke kamar mandi, berbeda 
dengan pernyataan dari partisipan 2 dan 4 yang menyatakan bahwa kendala selama melatih anak untuk buang air yaitu anak biasanya sudah tertidur dan susah dibangunkan

Sikap orang tua dalam melatih anak, apabila anak masih memiliki kebiasaan mengompol, berdasarkan wawancara yang telah dilakukan dengan 4 partisipan, dapat dilihat bahwa adanya persamaan jawaban antara partisipan 1, 23 dan 4, yaitu bahwa sikap orang tua ketika sesekali anak masih mengompol saat dilatih, orang tua tidak akan memarahi anaknya, dan memaklumi anak.

\section{Pembahasan}

A. Mengeksplorasi persepsi ibu tentang toilet training pada anak usia toddler.

1. Cara ibu membiasakan anak untuk buang air

Hasil penelitian menunjukkan bahwa ibu sudah memahami bagaimana cara ibu untuk membiasakan anak agar anak tidak mengompol, hal tersebut disampaikan melalui pernyataan-pernyataan oleh partisipan yaitu $(\mathrm{P} 1),(\mathrm{P} 2),(\mathrm{P} 3)$ dan $(\mathrm{P} 4)$ yang mengatakan bahwa bahwa cara untuk membiasakan anak agar tidak mengompol adalah membiasakan anak untuk buang air pada pagi hari setelah bangun tidur, 2 atau 3 jam setelah itu, ataupun malam sebelum tidur. Pernyataan tersebut didukung oleh jawaban dari triangulasi, dan diperkuat oleh teoriyang menyatakan bahwa melatih anak dalam toilet training dilakukan secara rutin kepada anak ketika anak terlihat ingin buang air, anak dibiarkan duduk di toilet pada waktu-waktu tertentu setiap hari, terutama 20 menit setelah bangun tidur dan seusai makan. ${ }^{[7]}$

2. Usia yang tepat melatih anak untuk buang air.

Penelitian menunjukkan bahwa ibu mulai mengajarkan anak untuk buang air pada usia 1 setengah tahun atau pada saat anak sudah pintar berjalan. Hal tersebut disampaikan melalui pernyataan-pernyataan oleh partisipan yaitu (P1) dan (P3) menyatakan bahwa anak sudah dilatih untuk buang air secara mandiri pada usia satu setengah tahun, dan menurut (P2) dan (P4) mulai melatih anak ketika anak sudah mulai pintar berjalan.Pernyataan tersebut didukung oleh triangulasi.Pernyataan tersebut diatas belum sesuai dengan teori yang yang mengatakan bahwa Fase anal (1-3 tahun/usia toddler), pada fase ini kesenangan atau kepuasan berpusat disekitar anus dan segala aktivitas yang berhubungan dengan anus. Anak pada fase ini sangat penting untuk diperkenalkan dengan toilet training, yaitu anak mulai diperkenalkan tentang rasa ingin buang air besar atau buang air kecil. ${ }^{[11]}$

3. Perlukah toilet training dilakukan sejak dini 
Penelitian menunjukkan bahwaibu sudah memahami perlunya toilet training diterapkan pada anak sejak dini. Hal tersebut disampaikan melalui pernyataanpernyataan oleh partisipan yaitu(P1), (P2) dan (P3) menyatakan bahwa membiasakan anak untuk buang air sejak dini perlu dilakukan untuk melatih kemandirian anak, serta menerapkan prilaku hidup bersih dan sehat, sedangkan menurut (P4) menyatakan bahwa membiasakan anak untuk buang air sejak dini perlu dilakukan agar anak tidak memiliki kebiasaan menggunakan pampers. Pernyataan tersebut di dukung oleh jawaban dari triangulasi dan diperkuat oleh teori yang mengatakan bahwa toilet training baik dilakukan sejak dini untuk menanamkan kebiasaan yang baik pada anak. [7]

\section{Dampak toilet training}

Penelitian menunjukkan bahwa tiga partisipan yaitu (P1) (P3) dan (P4) yang menyatakan bahwa dampak apabila anak tidak dilatih sejak dini untuk buang air anak menjadi tidak mandiri, selalu bergantung pada orang tua, malas, dan manja, sedangkan P2 mengatakan anak akan menjadi tidak teratur dan suka buang air sembarangan.Pernyataan diatas diperkuat oleh teori yang mengatakan bahwa dampak yang paling umum dalam kegagalan toilet training seperti adanya perlakuan atau aturan yang ketat bagi orang tua kepada anaknya yang dapat mengganggu kepribadian anak yang cenderung bersifat retentive dimana anak cenderung bersikap keras kepala bahkan kikir. ${ }^{[12]}$

B. Persepsi ibu tentang upaya yang dilakukan terhadap keberhasilan toilet training.

1. Persiapan dalam toilet training

Penelitian menunjukkan bahwa ibu sudah memahami hal yang harus dipersiapkan. Hal tersebut disampaikan melalui pernyataan-pernyataan oleh partisipan yaitu pernyataan (P1), (P2) dan (P3) yang mengatakan hal yang perlu dipersiapan ketika melatih anak untuk buang air secara mandiri adalah melihat dari minat atau kemauan anak, serta letak kamar mandi yang tidak jauh dari kamar tidur, sedangkan menurut (P4) hal yang perlu dipersiapkan terlebih dahulu adalah mengajarkan anak agar tidak takut dan trauma pada kamar mandi.

2. Jadwal dalam melatih anak untuk buang air.

Penelitian menunjukkan bahwa keempat partisipan (P1), (P2) (P3) dan (P4) mengatakan bahwa tidak ada jadwal yang pasti dalam melatih anak ketika buang air, tetapi orang tua selalu membawa anak ke toilet saat bangun tidur, maupun pada malam 
hari sebelum tidur. Pernyataan tersebut diperkuat oleh teori yang mengatakan bahwa membuatkan jadwal anak dalam toilet training juga sangat penting, Orang tua bisa menyusun jadwal dengan mudah ketika orang tua tahu dengan tepat kapan anaknya biasa buang air kecil (BAK) atau buang air besar (BAB). Orang tua bisa memilih waktu selama 4 kali dalam sehari untuk melatih anaknya yaitu pagi, siang, sore dan malam bila orang tua tidak mengetahui jadwal yang pasti buang air kecil atau buang air besar anak. ${ }^{[13]}$

3. Peran keluarga dalam keberhasilan toilet training.

Penelitian menunjukkan bahwa ibu memahami bahwa anggota keluarga yang lain yakni suami sangat berperan penting dalam membiasakan anak untuk buang air. Hal tersebut disampaikan melalui pernyataan-pernyataan oleh keempat partisipan yaitu (P1), (P2) (P3) dan (P4) yang mengatakan bahwa anggota keluarga yang juga paling banyak ikut berperan adalah suami. Hal ini sejalan dengan teori yang mengatakan bahwa Keterlibatan ayah dalam pengasuhan juga berperan dalam keberhasilan toilet training. Pendekatan muktahir yang digunakan dalam hubungan dan bayi baru lahir sama pentingnya dengan hubungan antara ibu dan bayi, sehigga dalam proses persalinan ibu di anjurkan di temani suami. ${ }^{[1]}$

C. Persepsi ibu tentang hambatan-hambatan yang dialami dalam toilet training.

1. Hambatan atau kendala dalam toilet training

Penelitian menunjukkan bahwa ibu memahami hambatan-hambatan yang sering dirasakannya ketika melatih anaknya untuk buang air. Hal tersebut disampaikan melalui pernyataan-pernyataan oleh 2 partisipan yaitu (P1), dan (P3) mengatakan bahwa hambatan atau kendala ketika melatih anak dalam toilet training adalah ada pada anak sendiri, sebab kadang anak rewel dan tidak mau diajak ke kamar mandi. Berbeda dengan (P2) dan (P4) yang mengatakan bahwa kendalanya karena anak biasanya sudah tertidur dan susah dibangunkan. Pernyataan tersebut diperkuat oleh teoriyang mengatakan bahwa orang tua selayaknya melihat kesiapan anak untuk toilet training terlebih dahulu kemudian memberitahukan tentang toilet training dengan anak agar anak tidak merasa terpaksa melakukannya. ${ }^{[13]}$

2. Sikap orang tua dalam melatih anak, apabila anak masih memiliki kebiasaan mengompol.

Hasil penelitian menunjukkan bahwa keempat partisipan yang mengatakan bahwa sikap orang tua ketika sesekali anak masih mengompol saat dilatih, orang tua tidak 
akan memarahi anaknya, melainkan memakluminya.Pernyataan tersebut diatas diperkuat oleh teori yang mengatakan bahwa anak sesekali enkopresis (mengompol) dalam masa toilet training itu merupakan hal yang normal. Anak apabila berhasil melakukan toilet training maka orang tua dapat memberikan pujian dan jangan menyalahkan apabila anak belum dapat melakukannya dengan baik. ${ }^{[7]}$

\section{Simpulan}

Persepsi ibu tentang toilet training pada anak usia toddler, tentang cara untuk membiasakan anak agar tidak mengompol yaitu dengan cara membiasakan anak untuk buang air pada pagi hari setelah bangun tidur, 2 atau 3 jam setelah itu, ataupun malam sebelum tidur. Usia untuk mulai melatih anak dalam toilet training setelah usia satu setengah tahun atau ketika anak sudah pandai berjalan. Membiasakan anak untuk buang air sejak dini perlu dilakukan untuk melatih kemandirian anak, serta menerapkan prilaku hidup bersih dan sehat, karena dampak apabila anak tidak dilatih sejak dini untuk buang air anak menjadi tidak mandiri, selalu bergantung pada orang tua, malas, dan manja.

Persepsi ibu tentang upaya yang di lakukan terhadap keberhasilan toilet training, bahwa untuk jadwal dalamtoilet training, yaitu tidak ada jadwal yang pasti dalam melatih anak ketika buang air, tetapi orang tua selalu membawa anak ke toilet saat bangun tidur, maupun pada malam hari sebelum tidur, dan anggota keluarga yang ikut berperan dalam toilet training adalah suami.

Persepsi ibu tentang hambatan-hambatan yang di alami dalam toilet training, hambatan atau kendala yang dialami dalam toilet training adalah ada pada anak sendiri, sebab kadang anak rewel dan tidak mau diajak kekamar mandi, dan sikap orang tua ketika sesekali anak masih mengompol saat dilatih, orang tua tidak akan memarahi anaknya, melainkan memakluminya.

\section{Saran}

Untuk itudiharapkan pada ibu balita untuk melatih toilet training pada anak mulai usia satu hingga 3 tahun, karena melatih anak sejak dini perlu dilakukan untuk menanamkan kebiasaan-kebiasaan baik pada anak, jadi tidak harus menunggu anak pandai berjalan terlebih dahulu.Untuk petugas kesehatan, agar lebih meningkatkan penyuluhan secara menyeluruh terkait toilet training pada anakusia toddler, agar para orang tua yang memiliki balita mendapatkan informasi terkait toilet training, dan bagi peneliti selanjutnya dalam mengambil 
data atau melakukan wawancara selain menggunakan pedoman wawancara agar lebih bisa dikembangkan lagi sesuai dengan keadaan responden berdasarkan tujuan yang ingin dicapai pada tujuan khusus.

\section{Daftar Referensi}

[1]Wong et. Al (2009). Buku Ajar Keperawatan Pediatrik ed.6 volume1, Jakarta: Rineka Cipta

[2]Kemenkes RI (2010). Persentase Jumlah Balita di Indonesia

[3]Lestari.S (2013). Psikologi Keluarga, Penanaman Nilai \& Penanganan Konflik Dalam Keluarga.Yogyakarta:Prenada Media Group

[4]Winardi (2007). Pengantar Tentang Teori Sistem dan Analisi Sistem. Bandung:Mandar Maju

[5]Robbins (2008). Prinsip-Prinsip Perilaku Organisasi. Jakarta : Erlangga

[6] Zaivera Ferdinand (2008). Mengenali dan Memahami Tumbuh Kembang Anak. Yogyakarta : Kata Hati

[7]Soetjiningsih (2014). Tumbuh Kembang Anak Edisi 2. Jakarta: Buku Kedokteran EGC

[8] Sugiyono (2009). Metode Penelitian Kualitatif dan Kuantitatif Dan R\&D. Bandung : Alfabeta

[9] Notoatmodjo (2010). Promosi Kesehatan dan Perilaku Kesehatan. Jakarta : Rineka Cipta

[10] Agus Salim (2009). Memahami Penelitian Kualitatif. Bandung: Alfabeta.

[11]Dr. Hadi Siswanto (2010). Pendidikan Kesehatan Anak Usia Dini. Yogyakarta:Pustaka Rihama

[12]Hidayat (2008).Pengantar Ilmu Keperawatan Anak I. Jakarta:SalembaMedika

[13] Sears William, MD (2009). Memahami Anak Rewel.Jakarta:Buah Hati 